\title{
External Factors Influencing Bid/No-Bid Decision for Supervision Consultant Service: A Case of Construction Project in Hanoi
}

\author{
Son Tung HA ${ }^{1}$, Manh Linh TRAN ${ }^{2}$, Huy Viet HOANG ${ }^{3}$, Van Hung TRAN ${ }^{4}$ \\ Received: March 15, 2020 Revised: March 28, 2020 Accepted: May 01, 2020
}

\begin{abstract}
This paper investigates the potential impact of external factors on bid/no-bid decision for supervision consultant service on construction project in Hanoi, the capital of Vietnam. The data used in this study are secondary data taken from annual reports and sourced from the Department of Public Procurement, Ministry of Planning and Investment in Hanoi. Besides, to identify the impact of external factors on bid/no-bid decision for supervision consultant service on construction project in Hanoi, the study collected data from 272 qualified questionnaires from bidders doing business in Hanoi. Cronbach's Alpha, EFA and regression model are used to explore the impact of each independent variable on bid/no-bid decision for supervision consultant service on construction project. The results show that three external determinants, including Project characteristic (PC), Legal codes (LC) and Competition (C) are affecting bid/no-bid decision for supervision consultant service on construction project in Hanoi. Among them, Project characteristic (PC) and Legal codes (LC) have positive relationships with bid/no-bid decision for supervision consultant service on construction project, whereas Competition (C) negatively affects bid/no-bid decision for supervision consultant service on construction project. It means the more contractors actually participate in a bid, the less bid/ no-bid decisions are made.
\end{abstract}

Keywords : External Factors, Bid/No Decision, Supervision Consultant Service, Construction Project, Hanoi.

JEL Classification Code: K2, L74, L78, M10, M21

\section{Introduction}

In essence, contractors may work directly with clients or take part in biddings. The bidding decision is more and more important because it takes much time, effort and resources of contractors. Construction projects are multifaceted because

${ }^{1}$ First Author and Corresponding Author. Lecturer, Head of Enterprise Management Division, Business Management Faculty, National Economics University, Vietnam [Postal Address: 207 Giai Phong Road, Dong Tam Ward, Hai Ba Trung District, Hanoi, 113068, Vietnam] Email: hasontungneu@yahoo.com

${ }^{2}$ Lecturer, Business Management Faculty, National Economics University, Vietnam. Email: linhtm.neu@gmail.com

${ }^{3}$ Lecturer, Business Management Faculty, National Economics University, Vietnam. Email: huyhv90@gmail.com

${ }^{4}$ Lecturer, Business Administration Institution, National Economics University, Vietnam. Email: tvhung161260@gmail.com

(c) Copyright: The Author(s)

This is an Open Access article distributed under the terms of the Creative Commons Attribution Non-Commercial License (http://Creativecommons.org/licenses/by-nc/4.0/) which permits unrestricted noncommercial use, distribution, and reproduction in any medium, provided the original work is properly cited. they encompass an array of human and non-human factors with changing uncertainties and intricate relationships among the related parties. Construction projects are initiated in complex and dynamic environments, resulting in circumstances of high uncertainty and risk that are compounded by demanding time constraints (Choudhry, Aslam, Hinze, \& Arain, 2014). Within the duration of a construction project, all designated stages (including feasibility studies, planning, design, procurement, construction, supervision and project commissioning) interact and are tightly linked to each other. The success of a project is determined by both the project management period and the operational period of the project (Pham, Nguyen, Tu, Pham, \& Le, 2019). Thus, supervision consultant service is the stage, which highly affects the construction project because it requires the contractor to meticulously observe on-site work to consult the construction team and ensure the quality of the construction project. Provided by construction companies, this service includes assurance in the execution of work and completion of work within the stipulated period, ensuring compliance with the design, technical specifications and various stipulations contained in the contract documents. 
Numerous researchers have established internal (firm related) or external (project-related and environmentrelated) factors affecting the bid or no-bid decision for a given bidding situation (Chisala, 2018). Despite the large body of literature relating to bid/no-bid decisions, there is a very limited research works conducted in the context of Vietnam in general and Hanoi in particular, and no study which examines the effect of external factors on supervision consultant service on construction project tendering has been done on a global scale. In this light, this paper investigates the potential impact of external factors on bid/no-bid decision for supervision consultant service on construction project in Hanoi, the capital of Vietnam. This paper, then, proposes some recommendations for businesses and regulators in Vietnam.

\section{Literature Review}

Construction projects are risky; such risks stem from the project's complexity and time constraint (Mulholland \& Christian, 1999). Construction risks exist in every phase of the project and may delay the project schedule, raise the cost and negatively affect the overall performance. Bunni (2005) posits that construction supervision is among the three main services that can be provided by a construction consulting firm, besides design and contractual document preparation. While firms usually have sufficient data to assess internal factors through various control mechanisms fairly, external factors are not under firms' control and thus, more complicated to evaluate. Though there is a rich set of academic works has examined factors influencing the bidding decision, most studies cover only the bidding decision for construction package, while the bidding decision for supervision consultant service on construction project has not been under investigation.

As the first study examines on bid/no-bid decision for supervision consultant service on construction project, this paper focuses on three external factors that affect bid/no-bid decision for supervision consultant service on construction project, namely: (i) Project characteristics; (ii) Legal codes and (iii) Competition.

\subsection{Project Characteristics}

Project characteristics, which pertain to the nature of a project, can affect businesses' decision to participate in the bidding procedure. Chua and Li (2000) list some factors related to project characteristics, including type of project, size of the project, cash-flow requirement, number of supervisory required, number of workers required, etc. Besides, the project's potential profit and project size are among the top five influencing factors of bidding decisions of Canadian firms (Fayek, Ghoshal, \& Abourizk, 1999;
Enshassi, Mohamed, \& El Karriri, 2010). Construction firms do not try to tender all possible projects, but prefer bidding projects in accordance with their size. Small firms aim for smaller projects and long-term projects, whereas large firms look for a wider spectrum of projects (Warsame, 2006). Bageis and Fortune (2006), Jarkas, Mubarak, and Kadri (2013), and Enshassi Mohamed and Karrini (2010) further list financial capacity of the client as having a significant impact on the bidding decision as an assurance for projects' cash flow. Ahmad and Minkarah (1988) conclude that the bidding process was greatly affected by subjective decisions such as type of job, size of the job, the need for work, owner, historic profit, degree of hazard, and location. In that light, Fayek, Young, and Duffield (1998) state that factors affecting the bidding decisions were project type, "availability of resources and people, experience, need for work, and location of the project. In addition, Chisala (2017) measures 'Project characteristics' factors by work regularity, project size, project type, project duration, project location, site conditions, and the public view of the project. To some extents, Alsaedi, Assaf, Hassanin and Abdallah (2019) measures the impact of project characteristics on contractors' bidding decisions for construction projects in Saudi Arabia by size of the job, type of the job, location of the project, duration, historic profit on similar jobs, job start time, degree of difficulty, degree of hazards, project cash flow, and rate of return.

\subsection{Legal Codes}

The significance of the legal environment has been stressed by Bommer, Gratto, Gravender, and Tuttle (1987). Newcombe, Langford, and Fellows (1990) emphasize the influence of the political environment and governmental law within which contractors operate. Even though the legal environment is seen as part of the cultural environment, here it has been treated as a separate issue (Fraser, 2000). In the same way that the professional environment can be operationalized into codes and code enforcement systems, so can the perception of the impact of the legal environment be viewed as the individual's own perception of legality, and fear of being held liable and facing penalties.

All the bidding activities must follow a standardized process stipulated in the corresponding law and regulations of the host country. A number of studies on the bid/no-bid decision insert the regulatory factors into their models. Chua and Li (2000) mention 'government regulation' while Ravanshadnia, Rajaie, and Abbasian (2011) use stabling law, standard, and requirements to measure 'risk' factor in bid/ no-bid decision. Respecting the law and following the code of tendering must be adhered to by any party, so that there are no deviations. Deviation from these obligations might constitute or precipitate collusive tendering (Fraser, 2000). 
The construction industry is also subject to government regulations (Enshassi Mohamed and Karrini, 2011). The bidding process on any project is supposed to be fair and objective; any deviation from these principles can be considered violating both the law and the business conduct.

\subsection{Competition}

Competition refers to the level of competition between contractors in the market at the time of bidding preparation (Admad, 1990). Hong and Shum (1999) state that an increase in the number of bidders has two counteracting effects on equilibrium bidding behaviors. First, the increased competition leads to more aggressive bidding, as each bidder tries to maintain their chances of winning against more rivals - this is called the competitive effect. Second, as the number of bidders increases, rational bidders will bid less aggressively in response - this is called the winner's curse effect. If the winner's curse effect is large enough, the possibility arises that prices will rise. Besides, competition with unknown bidders (e.g., using sealed envelopes) attracts more bidders than the open auctions and generated higher revenue (Athey, Levin, \& Seira, 2011; Enshassi, Mohamed, \& El Karriri, 2011). Then, Keung and Yiu (2015) identify that bidding behaviors as well as makeup selections greatly influence competitiveness of contractors. In addition, the threat of new entrants' competitors is one of the most important factors affecting the contractors' competitiveness and bidding strategies (Wheelen \& Hunger, 1998; Enshassi Mohamed and Karrini, 2011). Otherwise, the number of competitors in the tendering process that affect the bidding decision of contractors is mentioned in Shash (1993) in the UK, Enshassi Mohamed and Karrini (2010) in Gaza, and Alsaedi, Assaf, Hassanin and Abdallah (2019) in Saudi Arabia.

The above factors are expected to affect bid/no-bid decisions for supervision consultant service on construction project in Hanoi, Vietnam. The following result is illustrative.

\section{Research Methodology}

The review of the literature resulted in the identification of potential factors bid/no-bid decision for supervision consultant service on construction project. Inheriting the results of research by Alsaedi, Assaf, Hassanin and Abdallah (2019), Bagies and Fortune (2006), Chua and Li (2000), Fraser (2000), Le and Nguyen (2018), Ravanshadnia, Rajaie and Abbasian (2011), as well as using a qualitative research approach through interviews with experts to perform quantitative research, the authors identified three external determinants affecting bid/no-bid decision for supervision consultant service on construction project, namely: Project characteristics (PC), Legal codes (LC), and Competition (C).
Those factors were deemed to be suitable in the context of Vietnam. Also, conducting qualitative research through expert interviews helps us adjust and add observation variables to the questionnaire. After that, we organized a 5-point Likert scale questionnaire comprising nine observation variables. Independent variables were measured from 1 "Strongly disagree" to 5 "Strongly degree".

The Bidding Management Department of the Ministry of Planning and Investment maintains a detailed record of all contractors operating in Hanoi. Recent records indicate that there are 15,031 registered contractors in Hanoi. The record contains valuable information such as bidding contractor firms' statuses, names, addresses, degrees of classification and specialty. Data are collected through surveying bidders doing business in Hanoi. Among 300 were sent questionnaires, 300 were received and 272 of them were qualified. The sample size of this study is comparable to that of Hair, Babin, Anderson, and Black's (2018) study. Participants have been reviewed and approved for the legal entity status to participate in bidding.

The data collected from the survey has been synthesized and analyzed based on the SPSS 22 statistic software to make general points and findings. The detailed tools applied on SPSS 22.0 software include: (1) implementing Exploring Factor Analysis (EFA) to eliminate random variables; (2) evaluating Cronbach's Alpha reliability by applying Reliability Testing Scales; (3) implementing Confirmatory Factor Analysis (CFA) to confirm believable and practical value of scales; (4) testing Pearson correlation and testing research hypothesis; (5) implementing multiple regression analysis MRA and (6) conducting one-way ANOVA variance analysis. The proposed model is shown in Figure 1.

Dependent variable: Bid/no-bid decision for supervision consultant service on construction project (Tran \& Tran, 2018).

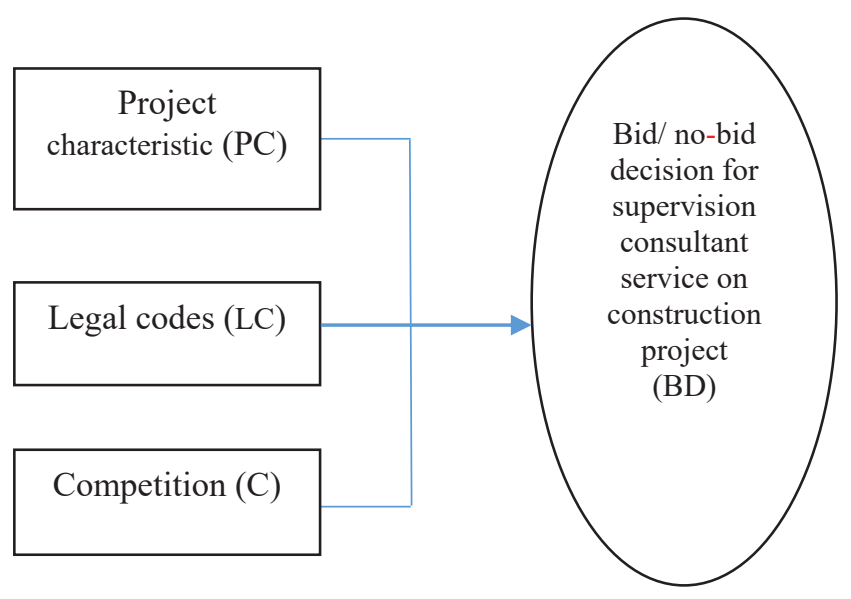

Figure 1. Research model 
Independent variables: The independent variables are described as below (see Table 1).

\section{Research Results}

\subsection{Descriptive Statistics}

Information on data collected is shown in Table 2 as below: Table 2 shows that among the 272 respondents, 161 respondents $(59.2 \%)$ were chairman, and 111 respondents $(40.8 \%)$ were authorized to answer the questionnaire.

Table 1: Determinants and its coding

\begin{tabular}{|c|l|}
\hline Code & \multicolumn{1}{|c|}{ Variables } \\
\hline Project characteristics (PC) \\
\hline PC1 & Size of project \\
\hline PC2 & Profitability \\
\hline PC3 & Reputation of the client \\
\hline Legal code $($ LC) \\
\hline LC1 & Whether there is a legal issue involved \\
\hline LC2 & Whether the action could be perceived as illegal \\
\hline LC3 & $\begin{array}{l}\text { Whether I would be held legally liable for the } \\
\text { action }\end{array}$ \\
\hline Competition (C) \\
\hline C1 & How many bidders will there be? \\
\hline C2 & Who else is likely to bid for this job? \\
\hline C3 & Are all bidders treated equally? \\
\hline
\end{tabular}

They also show 204 respondents (75\%) were male, 68 respondents $(25 \%)$ were female. Regarding age, the numbers of respondents under 40 years old, between 40 to 50 years old, and over 50 years old were $23(8.5 \%), 165(60.7 \%)$ and $84(30.9 \%)$, respectively.

\subsection{Quality Scale Analysis Result}

In order to minimize errors in the research model, scale analysis is employed. According to Hoang and Chu (2008), variables are accepted only when they satisfy the two following conditions: (i) the total correlation coefficient is larger than 0.3 and (ii) the Cronbach's Alpha coefficient is equal to or larger than 0.6. Analyzing Cronbach's Alpha of external environment determinants shows that bid/no-bid decision for supervision consultant service on construction project (BD) is impacted by three determinants with nine observed variables as shown in Table 3 . The result shows that all variables satisfy the two conditions; therefore, all variables are qualified (Hair, Babin, Anderson \& Black, 2018).

\subsection{Exploratory Factor Analysis (EFA)}

We conducted EFA and used the method to extract coefficients. The result of Component Analysis and Varimax, Analyzes yields nine attributes of independent variables. From Table 4, it can be seen that $\mathrm{KMO}=0.696$, which is between the range 0.5-1.0. Barlett's testimony shows its significance at $5 \%$ level, thus confirms the intercorrelation among the examined variables. After implementing the rotation matrix, three determinants with factor load factor are greater than 0.5; Eigenvalues are greater than 1; the

Table 2: Respondents by Responsibility, Gender and Age

\begin{tabular}{|c|c|c|c|c|c|}
\hline & & Frequency & Percent & Valid Percent & Cumulative Percent \\
\hline \multirow{13}{*}{ Valid } & Responsibility & & & & \\
\hline & Chairman & 161 & 59.2 & 59.2 & 59.2 \\
\hline & Authorized person & 111 & 40.8 & 40.8 & 100 \\
\hline & Total & 272 & 100.0 & 100.0 & \\
\hline & Gender & & & & \\
\hline & Male & 204 & 75 & 75 & 75 \\
\hline & Female & 68 & 25 & 25 & 100 \\
\hline & Total & 272 & 100.0 & 100.0 & \\
\hline & Age & & & & \\
\hline & Under 40 & 23 & 8.5 & 8.5 & 8.5 \\
\hline & $40-50$ & 165 & 60.7 & 60.7 & 69.2 \\
\hline & Over 50 & 84 & 30.9 & 30.9 & 100 \\
\hline & Total & 272 & 100.0 & 100.0 & \\
\hline
\end{tabular}


Son Tung HA, Manh Linh TRAN, Huy Viet HOANG, Van Hung TRAN /

Table 3: Results of analysis of Determinants Confidence of Scales in the Model

\begin{tabular}{|l|c|c|c|}
\hline \multicolumn{1}{|c|}{ Determinants } & $\mathbf{n}$ & Cronbach's Alpha & Corrected Item-Total Correlation \\
\hline Project characteristics $(P C)$ & 3 & 0.806 & 0.658 \\
\hline Size of project & & & 0.662 \\
\hline Profitability & & & 0.639 \\
\hline Reputation of the client & & & 0.770 \\
\hline Legal code (LC) & 3 & 0.825 & 0.574 \\
\hline Whether there is a legal issue involved & & & 0.752 \\
\hline Whether the action could be perceived as illegal & & & \\
\hline Whether I would be held legally liable for the action & & & 0.518 \\
\hline Competition (C) & 3 & 0.907 & 0.543 \\
\hline How many bidders will there be? & & & 0.618 \\
\hline Who else is likely to bid for this job? & & & \\
\hline Are all bidders treated equally? & & & \\
\hline
\end{tabular}

Table 4: KMO and Bartlett's Test

\begin{tabular}{|l|c|c|}
\hline \multicolumn{2}{|c|}{ Kaiser-Meyer-Olkin Measure of Sampling Adequacy. } & .696 \\
\hline Bartlett's Test of Sphericity & Approx. Chi-Square & 901.730 \\
\hline & Df & 36 \\
\cline { 2 - 3 } & Sig. & 0.000 \\
\hline
\end{tabular}

variance explained is $71,69 \%$. It demonstrates that research data analyzing factor discovery is appropriate. These results enable three determinants influencing bid/no-bid decision for supervision consultant service on construction project to be examined in this paper.

\subsection{Regression Model Analysis}

The multiple regression model is shown as following:

$$
\mathrm{BD}=\beta 0+\beta 1 \mathrm{PC}+\beta 2 \mathrm{LC}+\beta 3 \mathrm{C}+\varepsilon
$$

From the results of Table 5, 6, 7, we can see that in terms of multicollinearity testing, all variance inflation factor (VIF) of independent variables are under 2. Thus, the regression model does not suffer from severe multicollinearity (Hoang \& Chu, 2008). Durbin-Watson test statistics is 1.898, which implies that the multiple regression method can be applied for this model. Moreover, there is no trace of the autocorrelation problem (Hoang \& Chu, 2008). In terms of ANOVA testing result, $\mathrm{p}$-value lower than 0.05 implies that the data suit multiple regression model. R2 equals 0.421 , which means $42.1 \%$ of the total variation in the bid/no-bid decision of the construction contractors will be explained by the regression model. The results also show that all independent variables Project Characteristics (PC), Legal code (LC) and Competition (C) are significant to bid/no-bid decision for supervision consultant service on construction project. External factors influent bid/no-bid decision for supervision consultant service on construction project are shown in the following regression model:

$$
\mathrm{BD}=0.199 * \mathrm{PC}+0.483 * \mathrm{LC}-0.260 * \mathrm{C}
$$

\section{Discussion}

According to the research's results, there are two factors that affect positively and one factor that affect negatively on bid/no-bid decision for supervision consultant service on construction project including Project characteristics (PC), Legal code (LC) and Competition (C).

\subsection{Legal Code}

In Vietnam, the Construction Law, especially Bidding Law is being revised through the years. In that light, the 
Table 5: Model Summary

\begin{tabular}{|c|c|c|c|c|c|}
\hline Model & $\mathbf{R}$ & R Square & Adjusted R Square & Std. Error of the Estimate & Durbin-Watson \\
\hline 1 & $.649 a$ & .421 & .415 & .26743 & 1.898 \\
\hline
\end{tabular}

a. Predictors (Constant): PC, LC, C

b. Dependent Variable: BD

Table 6: Anova

\begin{tabular}{|l|c|c|c|c|c|}
\hline \multicolumn{1}{|c|}{ Model } & Sum of Squares & Df & Mean Square & F & Sig. \\
\hline 1. Regression & 13.951 & 3 & 4.650 & \\
Residual & 19.167 & 268 & .072 & 65.024 & $.000 \mathrm{~b}$ \\
Total & 33.118 & 271 & & \\
\hline
\end{tabular}

a. Dependent Variable: BD

b. Predictors: (Constant): PC, LC, C

Table 7: Coefficients ${ }^{a}$

\begin{tabular}{|c|c|c|c|c|c|c|c|}
\hline \multirow{2}{*}{ Model } & \multicolumn{2}{|c|}{$\begin{array}{c}\text { Unstandardized } \\
\text { Coefficients }\end{array}$} & $\begin{array}{c}\text { Standardized } \\
\text { Coefficients }\end{array}$ & \multirow{2}{*}{ T } & \multicolumn{2}{|c|}{ Sig. } & \multicolumn{2}{|c|}{$\begin{array}{c}\text { Collinearity } \\
\text { Statistics }\end{array}$} \\
\cline { 2 - 8 } & B & Std. & Beta & & 15.262 & .000 & \\
\hline (Constant) & 2.779 & .182 & & 4.182 & .000 & .956 & 1.046 \\
\hline PC & .108 & .026 & .199 & 10.086 & .000 & .943 & 1.060 \\
\hline LC & .309 & .031 & .483 & -5.527 & .000 & .979 & 1.021 \\
\hline C & -.164 & .030 & -.260 & & & \\
\hline
\end{tabular}

a Dependent Variable: BD

amended laws are more open and in sync with international regulations aiming to simplify administrative procedures and abolish business conditions. For contractors, they are very concerned whether they would be held legally liable for the action. The law violations, especially in the case of large projects, can damage the company reputation and brand. Besides, contractors are concerned about the violation of bidding law from the tenderers. The legal violations of the tenderers reduce the enthusiasm for the participation of contractors. Bidding law is also a guideline for investors, tenderers and contractors to implement all related activities.

The Bidding Law was enacted in 2005 and once amended under the 2009 Law Amending a Number of Articles of Laws Concerning Capital Construction Investment. The Law, together with its latest 2013 amendments and sub-law provisions, have laid a relatively complete legal foundation for management of bidding and public procurement activities nationwide. After years of implementation from the latest one, the bidding law has facilitated contractors and enterprises to participate in bidding package in various fields and levels. In particular, the implementation of the bidding law has supported investors to select the qualified and experienced contractors to ensure the quality, progress and finance of the project. Bidding has become a regular activity, contributing to increasing openness and fairness in the construction industry. These facts explain why bidding received strong support from society and investors.

Evidently, the application of the bidding law also reveals a number of problems, current bidding regulations are scattered in many legal documents. This results in overlaps and inconsistencies. Bidding for selecting construction contractors is governed by the Construction Law, while bidding for selecting investors to implement land-occupying projects or BOT, BTO or BT projects is regulated by the Investment Law. To some extents, there have no documents guiding the types of expenses related to the selection process of contractors; bidding professionalism is still limited, lacking uniformity among localities; monitoring and finding errors and negative activities are limited; and missing reporting regime. The Vietnamese economy has been integrated with the regional and global economies, including officially joining the World Trade Organization and entering into negotiations for the Trans-Pacific Strategic Economic Partnership Agreement and the Free 
Trade Agreement with the European Union. To enhance the positive impact on bid/no-bid decision for supervision consultant service on construction project and implement the country's international commitments, the Bidding Law, should be revised.

\subsection{Competition}

The competition factor negatively affects bid/no-bid decision for supervision consultant service on construction project. This means the more contractors actually participating in a bid, the less bid/ no-bid decision is made. After registering to bid for a certain package, the contractor is very interested in having anyone register to join the bid with them. If the number of participating contractors is large, it may lead to a decision that the contractor will no longer participate in this package. In Hanoi, there was a bidding package after it was announced, and 11 contractors were registered to participate. But by the time of bid closure, only three contractors submitted bids (really participate), and eight contractors withdrew in silence (not participating despite registration and purchasing bids). In fact, increasing competitiveness among bidders and their independence with the investor is one of the aims of the Vietnamese government (Tran \& Tran, 2018).

According to the reports of the Department of Public Procurement, Ministry of Planning and Investment collected by the authors for three years (2017, 2018 and 2019), Hanoi organized 5,789 bidding for consultancy service packages. The number of consultancy service bidding packages organized is very large and has still increased over the years. In 2018, the total number of consultancy service bidding packages was 1,590 packages, equaling more than 2.67 times that of 2017 (in 2017, the Hanoi organized 596 bidding packages for consultancy services). In 2019, the number of consultancy service bidding packages organized was 3,603; which is 2.27 times higher than in 2018 and 6.05 times higher than in 2017.

Nowadays, an increasing number of Vietnamese enterprises have been participating in the construction market. Though it shows that the capability of Vietnamese construction companies has been upgraded so that it is equal with foreign contractors, many other Vietnamese companies might lose the domestic market in the future because of outdated technology, lack of management skills and brain drain. Moreover, with the support from the government, there will be growing public infrastructure in rural areas and residence/social housing by 2020 . The need for this additional infrastructure increases construction demand and boosts competition in bidding as well.

In addition, the bid registration information of contractors also has a great influence on reducing the number of bidders participating in the recent time due to receiving information about the familiar contractors of the investors that will participate. Thanks to social media, information could spread. Of course, the social media is often used for different purposes based on different social networking communities (Lee, 2017). The appearance of unequal contractors with the remaining contractors made many contractors fluctuate. This scale is considered by most contractors to have a great influence on a contractor's decision to participate in a bid. In fact, many events show that the investor, in many ways, will inform 'wisely' participating contractors about the appearance of 'very heavy' competitor to reduce other contractors' interest.

\subsection{Project Characteristics}

In Hanoi, supervision consultant service packages on construction projects are often small size. Also, some are implemented by the contractor or sub-contractor and are often subdivided by investors. This reduces the interest of contractors. This is in stark contrast to construction bidding packages, which are often very large bidding packages.

In addition, there are still cases that discourage the contractor by giving the 'specific characteristics' requirements. These unique requirements would push many contractors out of the game. Some contractor representatives also affirmed that the specific requirements in the bidding documents are also prepared elaborately to eliminate nontarget contractors. According to the explanation of many bidders, the reason for 'special requirements' in the bidding documents is to restrict the participation of contractors who are not 'value groups' of the investor.

\section{Recommendations}

From the above research results, the authors propose some recommendations for supervision consultant service on construction projects. These recommendations focus on the analysis and evaluation of dependent variables and independent variables in the research model.

\subsection{Amend the Bidding Law in Vietnam}

The Vietnamese economy has been increasingly integrated with the regional and global economies. Thus, the amendment should refer to international regulations, especially international bidding practices, and be modified to suit specific circumstances and requirements in Vietnam. This is a very important criterion because it will cover and dominate bidding activities, which are taking place more and more with the participating contractors from many countries in the integration period. However, Le and Kim (2019) emphasize that globalization and liberalization cause difficulties for domestic firms, especially SMEs, which rely 
on government subsidies, to fairly compete with foreign firms.

Amending the bidding law in Vietnam should focus on enhancing competitiveness. The current processes and procedures for selecting contractors prescribed in the Bidding Law are relatively complicated. They need to be simplified so as to promote competitive bidding and encourage domestic businesses, especially small- and medium-sized ones, to participate in public procurement bidding. More than that, bidding law should focus more on fairness among contractors; separate survey design consultant from construction supervision consultants; and clarify the relationship between the head of the investor agency and the enterprise.

The Vietnamese government, in fact, has shown its effort to better manage the construction bidding process. The Bidding Law 2013 pushed a further step to prevent collusion in bidding practice by stipulating that (i) investors cannot own more than $30 \%$ of contractors and vice versa; (ii) negotiation of contract is compulsory before the selection is announced; (iii) expansion of inspection responsibilities; and (iv) new selection method which concentrates on the contractors' technical-financial capacity as well as their experience in the field. However, Hanoi is accelerating the implementation of industrialization and modernization, and such acceleration comes with the boost in demand for construction. Therefore, the bidding law needs to be regularly reviewed to foster economic efficiency and save investment capital besides the goal of ensuring the quality and progress of each project.

\subsection{Prohibit to Split the Bidding Packages Without a Proper Base}

The more attractive the bidding package of supervision consultant service on construction projects (the higher the value of bidding packages or the bigger the benefits for the contractor), the more likely the contractor will decide to participate in the bidding. However, in many different ways, investors always seek to subdivide the bidding package of supervision consultant service on construction projects. During the research process, the authors found that there are many packages of supervision consultant service on construction projects, which are split into very small parts; it affects bidding activities as well as the quality and efficiency of construction projects.

The splitting of bidding packages into smaller parts, especially in large projects, does bring benefits to investors such as better control of the progress and quality of contractors. For those projects, due to the enormous workload, contractors cannot manage to accomplish all required works, but need to hire subcontractors, which may not be adequate for the job. However, some investors may take advantage of the split to collude with specific bidders and hand over the job to them. Besides, it is harmful as it loses the uniformity of the whole construction work and reduces the quality of the project due to many subcontractors supervising different parts in different ways (Tran \& Tran, 2018). Thus, the regulation relating to bidding design should take this issue into account.

\subsection{Ensure the Goal of 'Fairness, Transparency and Economic Efficiency'}

When conducting bidding, it is necessary to secure 'competition in bidding' through ensuring the legal and financial independence between bidders and the following parties:

a) the investor, the bid solicitor;

b) other contractors participating in the bidding for one bidding package;

c) competent governmental authorities

Any activities that violate the law of bidding, other related laws and the promotion of fair and transparent bidding process (such as bribery, collusion, cheating, obstructing, etc.) must be strictly banned. The investors must not also state 'specific requirements' in the bidding documents in order to bring advantages to certain contractors. Increasing attention must be paid to the inspection, examination and supervision of bidding activities to ensure strict implementation of the law of bidding and relevant laws.

\section{References}

Ahmad, I. (1990). Decision-support system for modeling bid no-bid decision problem. Journal of Construction Engineering and Management, 116(4), 595-608. https://doi.org/10.1061/(ASCE)0733-9364(1990)116:4(595)

Ahmad, I., \& Minkarah, I. (1988). Questionnaire survey on bidding in construction. Journal of Management in Engineering, 4(3), 229-243. https://doi.org/10.1061/(ASCE)9742-597X(1988)4:3(229)

Alsaedi, M., Assaf, S., Hassanain, A. M., \& Abdallah, A. (2019). Factors affecting contractors' bidding decisions for construction projects in Saudi Arabia. Buildings, 9(2), 33-45. https://doi. org/10.3390/buildings9020033

Athey, S., Levin, J., \& Seira, E. (2011). Comparing open and sealed bid auctions: Theory and evidence from Timber Auctions. The Quarterly Journal of Economics, 126(1), 207-257. https://doi. org/10.2307/23015667

Bageis, A. S., \& Fortune, C. (2009). Factors affecting the bid/no bid decision in the Saudi Arabian construction contractors. Construction Management and Economics, 27, 53-71. https:// doi.org/10.1080/01446190802596220 
Bommer, M., Gratto, C., Gravender, J., \& Tuttle, M. (1987). A behavioral model of ethical and unethical decision making. Journal of Business Ethics, 6(4), 265-280.

Bunni, N. (2005). The FIDIC forms of contract (3rd ed.). Oxford, U.K: Wiley-Blackwell.

Chisala, M. (2017). Quantitative bid or no-bid decisionsupport model for contractors. Journal of Construction Engineering and Management, 143(12), 141-153. https://doi.org/10.1061/(ASCE)CO.1943-7862.0001407

Choudhry, R. M., Aslam, M. A., Hinze, J. W., \& Arain, F. M. (2014). Cost and schedule risk analysis of bridge construction in Pakistan: Establishing risk guidelines. Journal of Construction Engineering and Managenment, 140(7), 1-9. https://doi.org/10.1061/(ASCE)CO.1943-7862.0000857

Chua, D. K. H., \& Li, D. (2000). Key factors in bid reasoning model. Journal of Construction Engineering and Management, 126(5), 46-57. https://doi.org/10.1061/(ASCE)0733-9364(2000)126:5(349)

Enshassi, A., Mohamed, S., \& Karriri, E. A. (2010). Factors affecting the bid/no bid decision in the Palestinian construction industry. Journal of Financial Management of Property and Construction, 15(2), 118-142. https://doi.org/10.1108/13664381011063421

Enshassi, A., Mohamed, S., \& Karriri, E. A. (2011). Factors affecting the bid/no bid decision in the Gaza Strip - contractors's perspectives. Revista Ingenieria de Construccion, 26(1), 41-60.

Fayek, A., Ghoshal, I., \& Abourizk, S. M. (1999). A survey of bidding practices of Canadian civil engineering construction contractors. Canadian Journal of Civil Engineering, 26(1), 1325. https://doi.org/10.1139/198-038

Fayek, A., Young, D. M., \& Duffield, C. F. (1998). A survey of tendering practices in the Australian construction industry. Engineering Management Journal, 10(4), 29-34. https://doi.org/10.1080/10429247.1998.11415005

Fraser, Z. A. (2000). A classification of factors influencing participating in collusive tendering agreements. Journal of Business Ethics, 23(3), 269-282.

Jarkas, A. M., Mubarak, S. A., \& Kadri, C. Y. (2013). Critical factors determining bid/no bid decisions of contractors in Qatar. Journal of Management in Engineering, 30(4), 15-28. https://doi.org/10.1061/(ASCE)ME.1943-5479.0000223

Hair, J. F., Babin, B. J., Anderson, R. E., \& Black, W. C. (2018). Multivariate data analysis (8th ed.). Boston, MA: Cengage.

Hoang, T., \& Chu, N. M. N. (2008). Analysis of research data with SPSS. Ho Chi Minh City, Vietnam: Hong Duc Publishing House.

Hong, H., \& Shum, M. (2002). Increasing competition and the winner's curse: Evidence from procurement.
Review of Economic Studies, 69(4), 871-898. https://doi. org/10.1111/1467-937X.00229.

Keung, C. W., \& Yiu, T. W. (2015). Potential for long-term sustainability: A visit of bidding objectives and strategies from maintenance contractor's perspective. Facilities, 3(4), 177-194. https://doi.org/10.1108/F-07-2013-0056

Le, V. A., \& Nguyen, T. D. (2018). Factors affecting bid/nobid decision of construction projects in Vietnam. Science International (Lahore), 30(3), 445-449.

Le, A. H., \& Kim, T. (2019). The Effects of Economic Freedom on Firm Investment in Vietnam. Journal of Asian Finance, Economics and Business, 7(3), 9-15 https://doi.org/10.13106/jafeb.2020.vol7.no3.9

Lee, J.W. (2017). Critical Factors Affecting Consumer Acceptance of Online Health Communication: An Application of Service Quality Models. Journal of Asian Finance, Economics and Business, 4(3), 85-94. http://dx.doi.org/10.13106/jafeb.2017.vol4.no3.85

Mulholland, B., \& Christian, J. (1999). Risk assessment in construction schedules. Journal of Construction Engineering and Management, 125(1), 8-15.

Newcombe, R., Langford, D. A., \& Fellows, R. F. (1990). Construction management. London, UK: Mitchell.

Pham, V. Q., Nguyen, B. K. Q., Tu, B. V, Pham, H. T. T, \& Le T. Q. (2019). Critical Success Factors of Project Management: The Case of Construction Related Projects in Vietnam. Journal of Asian Finance, Economics and Business, 6(2), 223-230. https:// doi.org/10.13106/jafeb.2019.vol6.no2.223

Ravanshadnia, M., Rajaie, H., \& Abbasian, H. R. (2011). A comprehensive bid/no-bid decision making framework for construction companies. Iranian Journal of Science and Technology Transaction B: Engineering, 35(1), 95-103.

Shash, A. A. (1993). Factors considered in tendering decisions by top UK contractors. Construction Management and Economics, 11(2), 111-118. https://doi.org/10.1080/01446199300000004.

Tran, M. L, \& Tran, V. H (2018). Factors affecting participant decision in bidding for consultancy supervision packages of construction projects of contractors. Journal of Economic and Development, 255(2), 83-93.

Warsame, A. (2006). Construction costs: Central concepts, categories and determining factors ( $\mathrm{PhD}$ thesis report, Royal Institute of Technology, Stockhom). Available at: https://www. diva-portal.org/smash/get/diva2:10716/FULLTEXT01.pdf

Wheelen, T. L., \& Hunger J. D. (1998). Strategic Management and Business Policy (6th ed.). Upper Saddle River, NJ: Prentice Hall. 